\title{
Evolution of Eye Reduction and Loss in Trilobites and Some Related Fossil Arthropods
}

\author{
Brigitte Schoenemann ${ }^{a^{*}}$ \\ ${ }^{a}$ University of Cologne, Zoology Department (Neurobiology/Animal Physiology) and Institute of Biology Education, Herbert-Lewinstrasse \\ 10, D-50931 Cologne, Germany
}

\begin{abstract}
The fossil record of arthropod compound eyes reflects different modes and occasions of eye reduction and blindness. In the best-studied fossil examples, the trilobites [trilobites: extinct arthropods, dominant during the Palaeozoic], which have an excellent geological record, eyes are primary structures, and in all known genera which lack them, eye-loss is always secondary. Once the eyes were lost, they never were never re-established. The most striking examples occur in the Upper Devonian, when two unrelated major groups of trilobites, with different kinds of eyes, underwent eye reduction and even total loss of the eyes over the same time period, undoubtedly due to long-term environmental change. One reason is that a mud blanket spread over a vast area, there was no firm substrate, and many trilobites became small and many became endobenthic, reducing or losing their eyes in the process. Toxic environmental conditions may also have had an effect. Certain coeval forms remained, however, which still possess perfectly good compound eyes. Either they found vacant refuges where they could survive, or alternatively their visual systems were elaborate enough to adapt to the changing conditions. Another inducement for evolving small, reduced compound eyes is to become a tiny organism oneself, with simply not enough space to establish a regular and functional compound eye, and in such minaturised eyes special adaptations for capturing enough photons are necessary. Thus very small compound eyes often establish wide acceptance angles of their ommatidia, collecting light over large angular ranges of space and it is beneficial to have a wide rhabdom provided that it is short, has a wide lens diameter, and perhaps even possess highly sensitive receptor cells. We find such a miniaturised system in the first recorded planktonic trilobite. Another kind of reduction of a compound eye, or parts of it, also occurs, if selective pressure claims for a high specialisation of eyes that results in several facets fusing into a single functional unit. This probably can be found in phacopid trilobites, $\sim 400$ million years old. Here the enlarged aperture of a resulting large lens may allow vision under dim light conditions such as at greater depth. The fossil record gives relatively little evidence about parasites, which often have reduced eyes. Agnostida are blind relatives of trilobites which lived during the Cambrian and Ordovician. An early suggestion was that some of these were parasitic, but this was never commonly adopted. Finally penstastomids (Crustacea), worm-like parasitic organisms, already have been blind from the Cambrian ( 487Ma).
\end{abstract}

\section{Keywords:}

Blindness;

Eye Reduction;

Compound Eye;

Eye;

Vision;

Energy Costs Of Vision;

Evolution;

Biodiversification;

Adaptation;

Ecological Niche;

Plankton;

Deep Sea;

Miniaturization;

Optics;

Palaeozoic;

Trilobite;

Crustacean;

Arthropod;

Invertebrate;

Plankton.

Article History:

Received: 17 August 2018

Accepted: 10 October 2018

\section{1- Introduction}

Having considered not just compound or camera-lens eyes, able to form images, but all light sensitive structures of organisms, one may agree with Michael Land's and Russell Fernald's opinion, that "Since the earth formed more than 5 billion years ago, sunlight has been the most potent selective force to control the evolution of living organisms" [1].

The earliest known eyes can be traced back to approximately 542 million years ago (Mya), the Lower Cambrian. In a prior period, the Ediacaran (635-542 Mya), the only metazoans were the flat jellylike organisms lying or possibly

\footnotetext{
* CONTACT: B.Schoenemann@uni-koeln.de

DOI: http://dx.doi.org/10.28991/esj-2018-01151

(C) This is an open access article under the CC-BY license (https://creativecommons.org/licenses/by/4.0/).
} 
gliding on the floor of the sea. As yet there existed no free-swimming, pelagic organisms and in the world they inhabited there were no predators, no prey - and no eyes [2- 4]. Eyes may be considered as sensory organs that provide an organism with information about the distribution of light in the environment (after [5]), but eyes do not necessarily have to be image formers.

The first eyes of which we have knowledge probably originated during the so-called 'Cambrian Explosion' beginning 541 million years ago (Mya), and many of the marine invertebrates of the early Cambrian already were equipped with compound eyes or simple lens eyes [6-12]. During a very short interval of time, ca. (ca. 20 - 25 mya) recognizable fossils of all modern phyla appeared, but they most likely appeared over the course of at least 100-200 million years and much of the diversification happened in the Ediacaran [13]. During the Cambrian, and probably earlier, the first predators originated, and thus began a competition, or 'arms-race' between prey and predator. Having the most advantageous visual system became a primary driver for the evolution of ecosystems and their dynamics. This conception is formulated in the well-known 'Light Switch Theory' by Andrew [14, 15]. The faunas of the Cambrian were dominated by marine arthropods, many exhibiting magnificent compound eyes, as found in localities with exceptional preservation, the socalled Fossil Lagerstätten, such as those of Chengjiang (south-west China), Burgess Shale (Canada), and others. The oldest known eye in the fossil record that has been possible to analyse is the compound eye of a redlichiid trilobite from Estonia, East Baltic, dated from the very base of the lower Cambrian and thus is even older than the main events of the Cambrian Explosion. It shows a proper ommatidial structure, but as yet no clear dioptric apparatus [16].

\section{2- Why Should Animals Lose Their Eyes?}

Amongst animals living today, as e.g. among fish, amphibians, arthropods or molluscs, there are numerous examples of eye reduction or even secondary acquired eye loss, caused by various circumstances. That the resulting poor vision or even blindness is evidently secondary, witness genes still present today, which encode the development and structure of the former eyes. They even express information, because the resulting proteins belong essentially to reaction chains of the organism's metabolism. Several important examples are given in this volume (amphibians [17], mammals [18], molluscs [19], insects and crustaceans [20, 21] a comprehensive overview is given by [24]. In fossils such access to genetics is not possible, but it might be interesting to trace up conditions and environments during the earth history that lead to eye reduction or sometimes even eye loss to obtain insights and make understandable reasons and principles, perhaps even pathways, that gave rise to later secondary blindness. We shall use the example of trilobites, extinct arthropods that dominated the faunae of the Palaeozoic, and some of their relatives, because trilobites provide the best evaluated fossil record in this respect.

The occurrence of eye reduction and even eye loss can be observed across animal diversity under decreased or absent levels of light, either associated with particular life styles or certain habitats. There is no consensus about the evolutionary mechanisms, the more as there seems to exist a certain plasticity, and apparently there are no morphological or developmental constraints [24].

Here we explore four approaches to this problem, exemplifying the principles mostly on trilobites, since they have the most comprehensive fossil record. The most evident is the invasion of (i) lightless environments; the deep-sea realm, submarine caves, life within the sediment (endobenthy). That not enough photons may be available for photoreceptors to work efficiently, also may occur in very small eyes of tiny animals. These, however, often adapt to their miniaturisation (ii), by developing wide apertures (high F-numbers), wide acceptance angles of the optical system, specialised light-perceiving structures (wide rhabdoms) or sensitive receptors. Thirdly (iii) have endoparastitism; such organisms are invariably blind. Finally reduction of eyes may be 'used' (iv) to form new, more specialised systems, such as the schizochroal eyes of trilobites.

Compound eyes are characteristic for all arthropods, and they are plesiomorphic. They consist of repeated, identical units (ommatidia), from the outer side seen as facets Figure 1 B, C. There are some few of them in worker ants of certain species, and up to several ten-thousands in some dragonflies. The oldest type, still very common among diurnal insects and crustaceans, is the so-called focal apposition eye. Here the light is focused by a dioptric apparatus, consisting in a terrestrial system of a cuticular light-refracting lens and a clear crystalline cone. In aquatic systems the difference of refractive indexes of water and chitin of the cuticle is not high enough to refract light effectively, so the crystalline cone usually is formed as an index gradient lens. The light is concentrated onto the top of a light guiding structure, the rhabdom, which is part of the receptor cells. Each of the ommatidia is isolated optically from its neighbours by screening pigment cells Figure 1D. Because all contrasts in the field of view of one. 


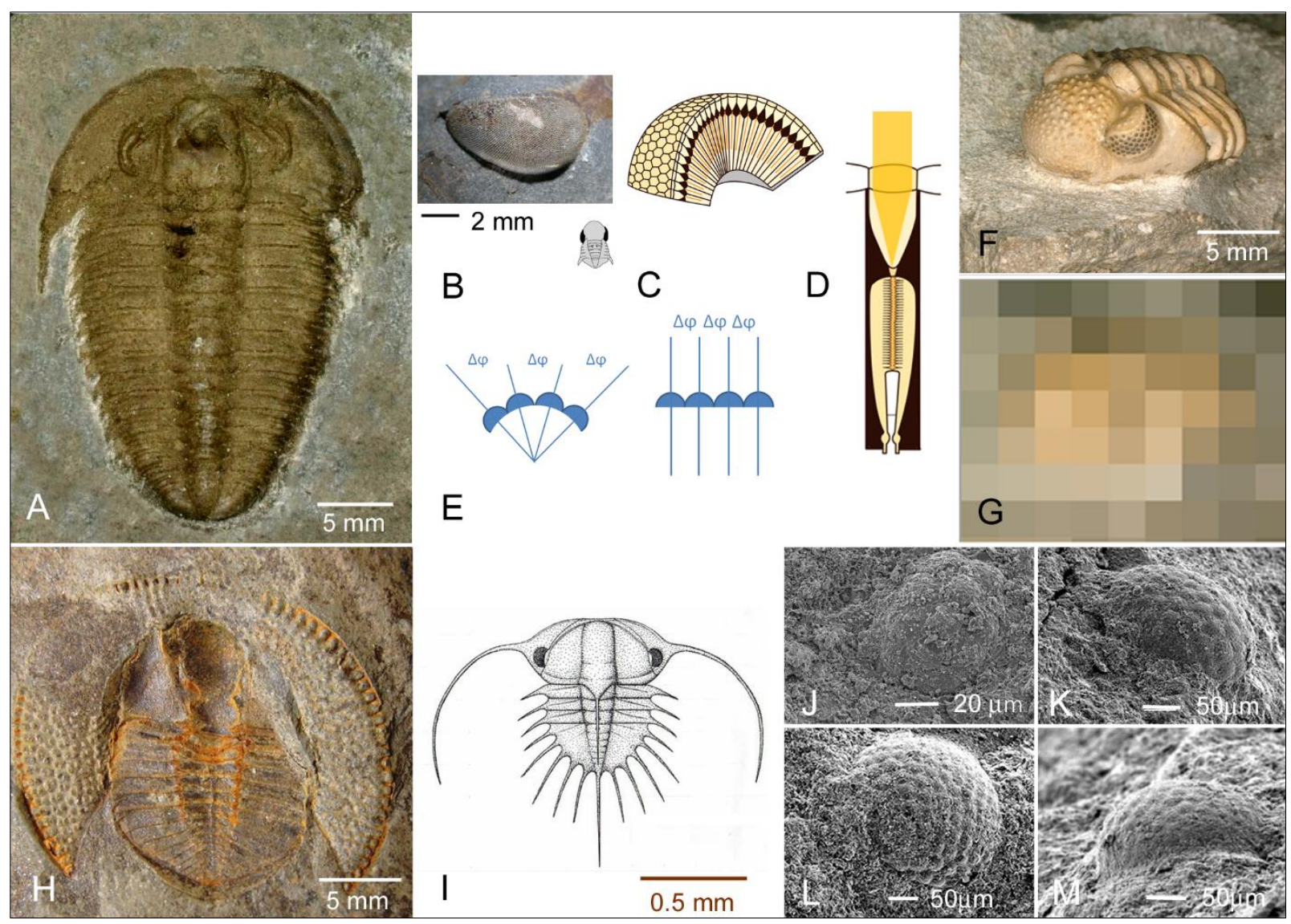

Figure 1. Trilobite compound eyes. (A) Irina oculata. Ordovician E2, Krasnojarsk, Russia, with reniform holochroal eyes. (B) Holochroal compound eye of the trilobite Pricyclopyge prisca, Ordovician, Bohemia (insert). (C) Schematic drawing of a compound eye. (D) Schematic drawing of how an apposition compound eye functions. (E) Optical axes and the fineness of scanning. (F) Phacopid trilobite Geesops schlotheimi Middle Devonian, Auberg/Gerolstein, Germany. Note the schizochral eye with widely separated lenses. (G) $E$ seen in an appositional-like mode with 63 facets, comparable to the specimen in $E$. (H) Declivolithus alfredi, Ordovician, El Kaid Errami, Morocco. Blind trilobite that lived in deep waters. (I) Ctenopyge ceciliae, tiny trilobite, Ordovician, Röstånga (Skane), Sweden. Probably the first planktonic trilobite. (J-M) Ontogenetic sequence of compound eyes of $\mathrm{C}$. ceciliae.

Facet are combined in that way, there may result an average impression, and over the whole compound eye a mosaiclike representation of the environment Figure 1G, [25]. Like pixels in a computer graphic, thus the number of facets defines the acuity of vision, among other factors as the acceptance angle of the rhabdom. Not necessarily, however, all information of the receptor cells is just averaged or pooled. Separate photoreceptors within modern ommatidia can sample different properties of light (e.g. light of different wavelengths or light with different planes of polarisation). Here it is more likely that information is compared between photoreceptors in an ommatidium, even if all of the photoreceptors are sampling the same region of visual space. Furthermore, during evolution there have developed more sophisticated systems, in which compound eyes are able to work better under dim-light conditions, where the isolation between the ommatidia is suspended, and neighbouring facets support each other in capturing photons (superposition eyes) $[5,26,27]$.

Trilobites Acquired blindness is rarely reported in the fossil record, and so the considerations here are focused on trilobites. Trilobites are extinct arthropods that dominated the Palaeozoic, in consequence of which they are amongst the most extensively investigated organisms of the fossil record. Being equipped with 'elaborated' compound eyes from their very beginning in the fossil record Figure $1 \mathrm{~A}$, they show all relevant principles of eye reduction and eye loss during the course of time. In some systematic groups even transitions from proper compound eyes to blindness were investigated by several authors, and so we shall lay the focus on them in this review. The systematic assignment of trilobites is still under discussion [28-30]. Recent analyses of Panarthropoda suggest that trilobites are one of the two major branches of Artiopoda [31]. The latter may be a clade in the stem group of Mandibulata or Euarthropoda as a whole or may give rise to the crown group of Euarthropoda. They appear at the base of the Cambrian explosion, already well equipped with highly 'elaborate' compound eyes, and they became extinct in the late Permian after some 270 million years of successful existence. During the Cambrian the great majority of trilobites were benthic, walking or gliding over the seafloor or excavating shallow burrows into the sea floor and feeding on organic material in and on the sea floor. Some Ordovician forms were pelagic. Whereas it was during the Cambrian that all known phyla appeared, it was during 
the following Ordovician that many previously unoccupied ecological niches were invaded and countless new species developed; this was the so-called 'Great Ordovician Biodiversification Event' (GOBE). At different times, a number of important groups of trilobites lost their eyes altogether. For example, the trinucleids, invading deep waters, became all blind forms in which the outer part of the cephalon is modified as a pitted fringe, Figure $1 \mathrm{H}$, which has been interpreted as some kind of filtering device, separating out edible particles from the ground [32]. But of all the instances of eyereduction and blindness in trilobites the most dramatic were in the late Devonian.

\section{3- Eye-reduction and Blindness in Late Devonian Trilobites Caused by Environmental Changes}

\section{3-1- Environmental Changes in the late Devonian}

Trilobites, as mentioned, were the dominant arthropods that ruled the Palaeozoic for some 270 million years, and may mirror nicely the adaptations of visual capacities to environmental changes [33]. While in the beginning they all seem to have been benthic, during the Ordovician they colonised many different ecological niches - morphological characteristics indicate that some became pelagic and planktonic, but most of them lived close to the shelves in or around the reefs, and thus depended on the stability and persistence of the reefs. During the Paleozoic several mass extinction events occurred which also affected trilobites. Here we focus on the two so-called Kellwasser- and Hangenberg-Events in the late Devonian, and as for all trilobites, the severe extinction at the end of the Permian (PT-Event, 'Great Dying', 252Mya). The late Devonian extinction event Frasnian-Famennian period, 375-360 Mya, [34] is one of the five major extinction events in the earth history, though it is still uncertain when it exactly happened and whether it was one extended phase, or more. Probably there were about seven to ten pulses in a period of about 25 million years [35, 36].That the Kellwasser Event was more than one event also is argued in the more recent article of McNamara and Feist in 2016 [37]. Finally this period was closed by the quite distinct, so-called Hangenberg Event at the end of the Devonian [38]. During the Kellwasser Event ( $\sim 372$ mya) probably more than $19 \%$ of all families, about $50 \%$ of all genera, and $\sim 70-80 \%$ of all animal species existing became extinct, amongst them especially the reef colonisers, and many of the last trilobites reduced or lost their eyes Figure 2A-C,E,F,H,L; 3. Thirteen million years later occurred another mass extinction event, the so-called Hangenberg Event ( 359 mya, [39], at the cusp of the Carboniferous (FamennianTournaisian-transition), which was much less distinct than the Kellwasser Event and affecting mainly terrestrial forms [40].

The catastrophe of the late Devonian probably started with the opening of a superplume in the center of Siberia $~ 375$ Mya (for overview see [41]. According to one current model, the intense volcanism led to a warming of the atmosphere worldwide, and the water temperature in the oceans increased to more than 32 degrees. This was a worldwide event, and ocean currents ceased because the temperature gradient across the planet declined dramatically. On the continents heavy rainfalls occurred and according to one theory, due to a high greenhouse effect caused by the high volcanic $\mathrm{CO}_{2}$ emissions, land plants grew very successfully. Their organic material was flushed by the rivers into the sea, and in the hypereutrophic shore waters there arose algal and bacterial blooms, consuming great quantities of oxygen. In the shelf areas, close to the continents, living organisms died out and thus during the Kellwasser events reef organisms especially became dispersed and many forms even went extinct [40]. Ironically, when the volcanic activity finally had calmed down, the excessive plant growth reduced the atmospheric $\mathrm{CO}_{2}$ levels. It is assumed that the loss of this $\mathrm{CO}_{2}$ contributed to a global cooling and finally a relatively short but intense period of glaciation in the landmasses of Gondwana, now shifted far to the south, took place at the very end of the Devonian (Hangenberg Event, [35, 42, 43]. While the Kellwasser Events had the severest effects on marine organisms such as trilobites e.g. [44, 45], the Hangenberg Event involved mostly terrestrial organisms e.g. [40]. Dark or black shales, devoid or poor of fossils are a present testament to the history of these dysaerobic periods today. 


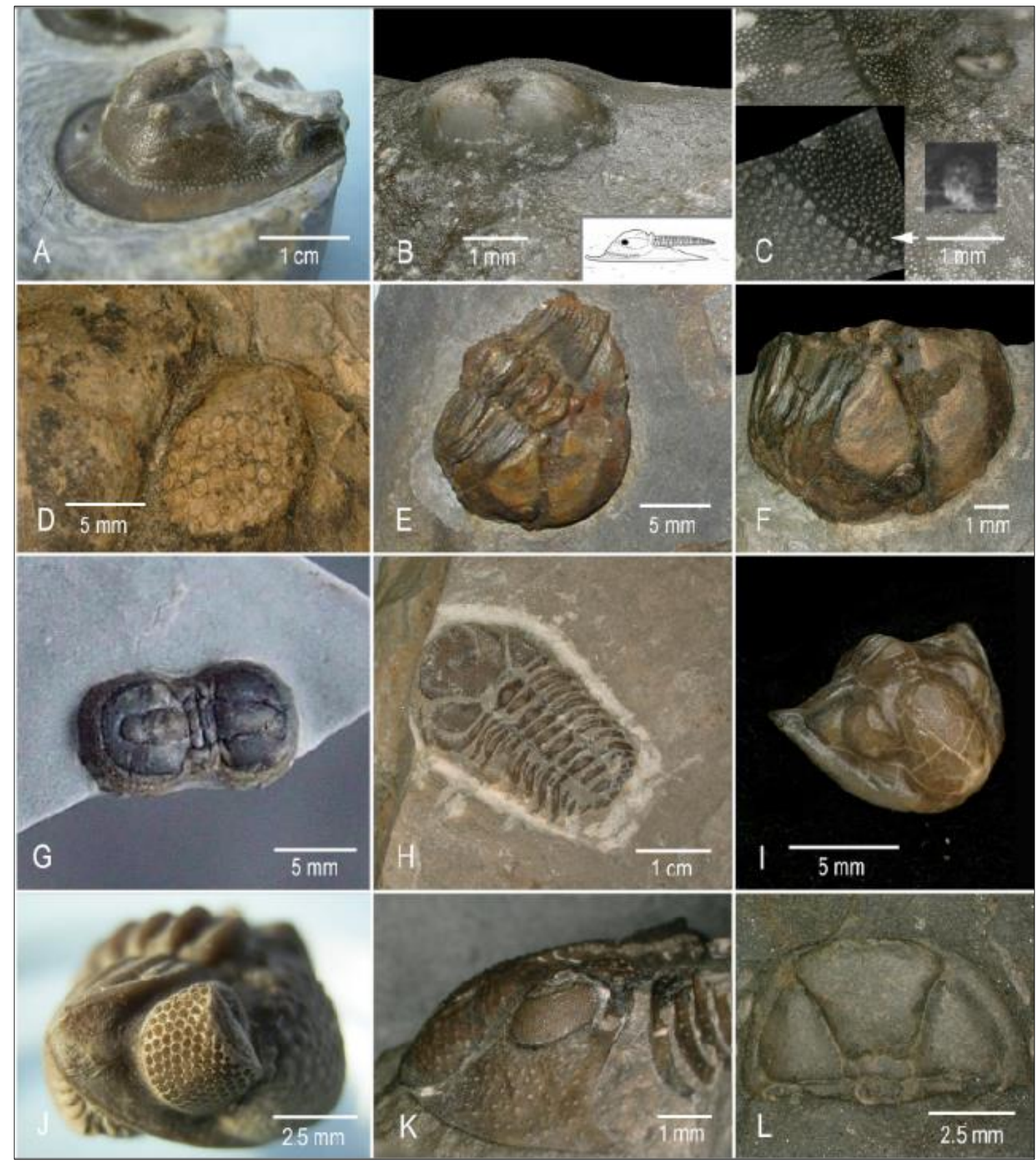

Figure 2. Trilobites blind, with reduced eyes or with well developed compound eyes. (A) Harpes macrocephalus (trilobite), Middle Devonian (Eifelium), Auberg/Gerolstein, Germany. (B) Reduced eye of a harpetid trilobite. Insert: Mode of life in harpetid trilobites. (C) Seam of the cephalon with numerous pores, interpreted as chemosensoric organs forming a "compound nose". Small insert: pore. (D) Well developed schizochroal eye of Phacops (Omegops) accipitrinus, upper Devonian (late Famennian), Langenhorst/Velbert Germany. (E, F) Struveaspis cf. micromma, with reduced schizochroal eye, middle Devonian, Haiger, Germany. (G) Itagnostus interstrictus (Peronopsis interstricta), middle Cambrian, Wheeler Shale USA, perhaps a blind parasitic trilobite. (H) Trimerocephalus caecus, blind trilobite, Upper Devonian (Lower Famennian), Holy Cross Mountains, Poland. (I) Ditomopyge decurata, Permian, Kansas, USA, one of the last trilobites, but well equipped with big holochroal eyes. (J) Pedinopariops brongniarti, middle Devonian (Eifelium), Auberg/Gerolstein Germany, with typical schizochroal eye. (K) Scutellum flabelliferum, middle Devonian (Eifelium), Gees/Gerolstein, Germany, with typical holochroal eye. (L) Ductina ductifrons, blind trilobite, Upper Devonian (Famenne), Eskesberg/Wuppertal, Germany.

\section{3-2- Holochroal-Eyed Proetids and Schizochroal-Eyed Phacopids}

The trilobites, as a whole, had undergone a stepwise decline from the mid-Devonian onwards, leaving only five orders, of which only two, the Phacopida and Proetida survived into the Famennian, the final stage of the Devonian. In the Middle Devonian the great majority of these had normal eyes. But throughout the Upper Devonian, and in both proetids and phacopids simultaneously, eye-reduction and blindness are characteristic, moreover occurring in many parts of the world, Europe, North Africa, China, and Australia (for a recent review see [37]).

There are two kinds of trilobite eyes. The basic kind is the so-called holochroal eye, which is present in the earliest 
trilobites at the beginning of the Cambrian and persists through all 'trilobite times' until their final extinction in the Permian Figure 1 B, J-M and 2 A, B, I, K. This is the most common type of eye among all groups of trilobites, and it is present in the proetids. The holochroal eye may consist of several up to ten-thousands of facets. Normally each visual unit consists of a lens and a sensory unit underneath, while all lenses are covered by a common pellucid membrane, the cornea. Both the lenses and the cornea of trilobites consist of primary calcite, unique in the arthropod realm. The sensory unit seems to be an ommatidium as typical for apposition eyes [16], similar to those of modern bees or other diurnal insects and many crustaceans. The other kind of eye is the schizochroal eye, found only in the phacopids Figure $1 \mathrm{~F}$ and 2 D-F, J. Here the lenses are less numerous than in the holochroal eyes, and much wider. The lenses are fully separated from each other, by the same material that forms the exoskeleton, unlike those of holochroal eyes. Each lens is topped by a separate membrane, forming a translucent cornea continuing to a capsule below the lens, containing the sensory unit. The nature of this sublensar sensory unit was first described and illustrated by Schoenemann and Clarkson in2013 [45]. Since the earliest stages of development of holochroal eyes during ontogeny are remarkably like miniature schizochroal eyes, it is highly probable that the latter originated by paedomorphosis, when juvenile or even larval traits are retained into later life $[16,46]$. This would account for the relatively large, separate lenses of the schizochroal eye. With regard, however, to the sublensar, photoreceptive organs, it seems rather probable that in the eyes of phacopid trilobites several ommatidia fused to one under a big lens to share the large aperture to capture light efficiently under dim light conditions, possibly sharing different functions (Schoenemann and Clarkson, curr. res.). A similar principle can be found in extant crustaceans such as of the order Ampeliscida (deep sea amphipodes) [47, 48].

Probably the first scientist to document a gradual reduction of the eyes of trilobites during the Upper Devonian (Figure 3D) were Rudolf and Emma Richter [49], then working at the Senckenberg Museum in Frankfurt. In their substantial and classical systematic monograph „Die Trilobiten des Oberdevons“(1926) there are twelve pages of illustrations, which show remarkable details of oculate, reduced-eyed, and blind forms. They describe, how in both, the schizochroal-eyed Phacopida and the holochroal-eyed Proetida, during the upper Devonian the compound eyes become smaller [49]. Many further studies made more recently have added much new information. Feist and colleagues [50-59] to name but a few authors) undertook closer investigations and they describe several modes of eye reduction in both phacopids and proetids Figure 3. It is highly probable that heterochrony, especially paedomorphosis, was an important control of eye-reduction [52, 60]. In phacopid trilobites, during the larval stages the eyes lie far to the front of the head, and while the rest of the trilobite developed regularly, as soon as the selective pressure on the elaborate compound eyes released, these remained in a larval condition Figure 3 C, E, G [46].

In many holochroal eyes, in the course of time these became simply smaller and smaller until they vanished completely $[44,51,61]$. Besides the phacopids and proetids, harpetid trilobites are present in the Devonian, though the last representatives had vanished by the end of the Frasnian [37, 62]. Harpetid trilobites Figure 2A-C and 3F, are very unusual looking forms with an extended, horse-shoe shaped cephalon with a broad brim, probably adapted for gliding over the floor of the sea. The eyes are notably reduced Figure 2A, B. Feist and Schindler describe that while in some late Frasnian harpetid forms the eyes become reduced further, the brim of the cephalon widens. This brim is very thin and perforated by thousands of small pits. It is suggested that the characteristic harpetid fringe functioned as a secondary respiratory structure while the small pits provide an increased respiratory surface $[60,63]$. The pits also may have been the sites of chemosensors, the structure shown in Figure 2 (insert) well might represent a typical chemsonesoric bud. Perhaps both was represented in the fringes of harpetids. The idea of chemosensoric properties lead to the suggestion that here we find the change from a compound eye to a 'compound nose' [54]. Alternatively they may have been the sites of vibrosensory organs, in which case the brim may have formed a 'compound ear' (J. K. Ingham pers. comm). 


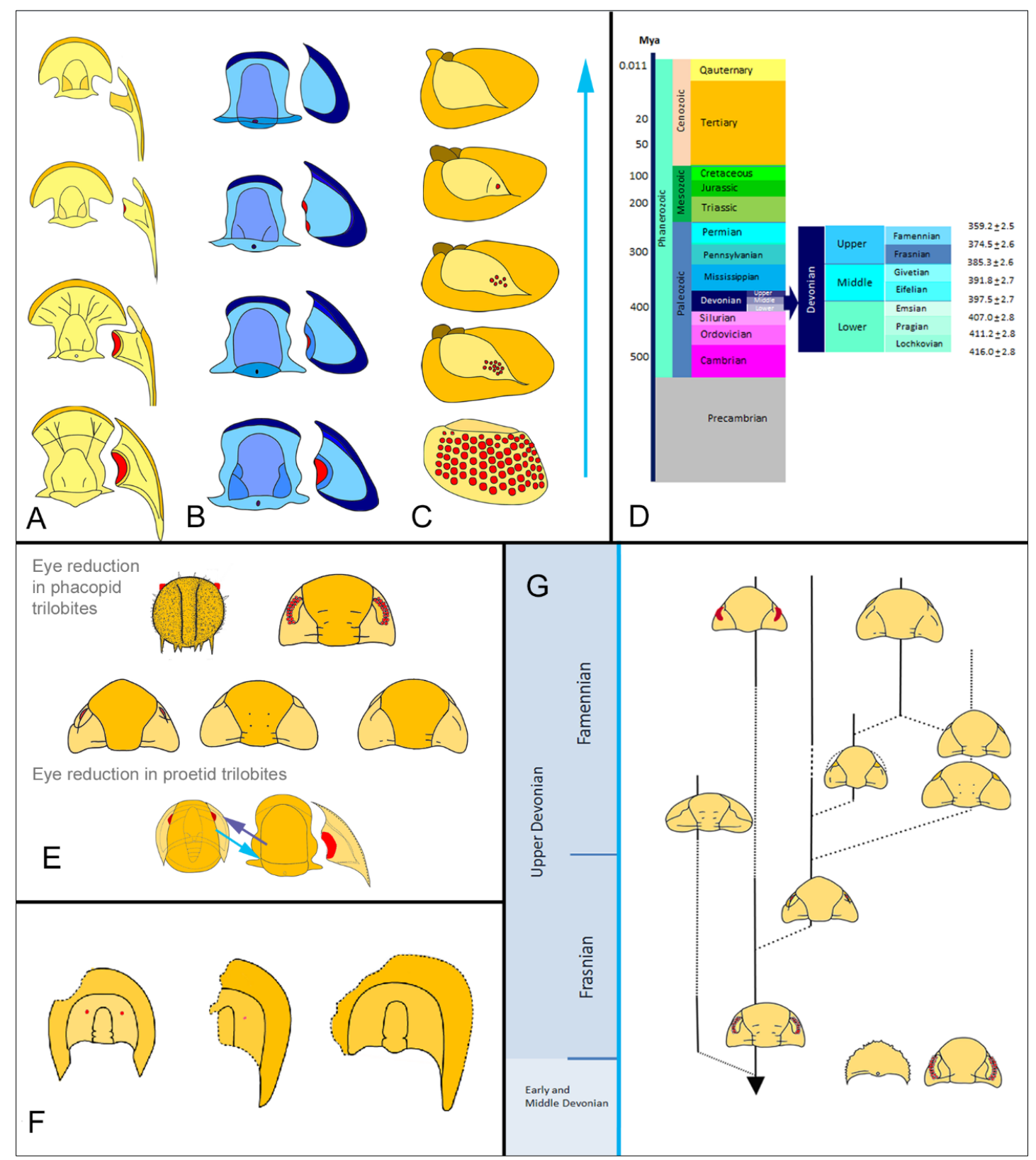

Figure 3. Eye reduction and blindness in some parallel Devonian trilobite lineages. (A) Tropidocoryphinae (Proetida), Givetian-Frasnian, with unidirectional morphological change and eye reduction. (B) Palpebralia (Proetida), Frasnian, showing progressive eye reduction. (C) Cryphops (Phacopida), base: typical phacopid eye, upwards: progressive eye reduction. (D) Geological time scale. (E) Eye shifting paedomorphically to the front in phacopid trilobites and ontogentic change of eye position during ontogenetic development in proetid trilobites. (F) Harpes neogracilis (Harpetida), Late Frasnian, in this species eyes are reduced, while the cephalic rim enlarges to a 'compound nose' rsp. 'compound ear'. (G) Eye reduction in Late Devonian lineages (comp. Feist 1995), Cyrtosymbolinae, Famennian, progressive eye reduction. (A, E-G) after Feist 1995, (B, C) after Feist 1991, (D, H) after Feist and Schindler 1994.

\section{3-3- Heroes and Survivors}

One of the last trilobites of the Devonian, the phacopid Omegops accipitrinus Struve 1976 Figure 2D was so named by its describer, because $\Omega$ is the last letter in the Greek alphabet [64]. Despite the prevalence of reduced eyes in the Upper Devonian, Omegops clearly has large schizochroal eyes. It seems most likely that hypereutrophic conditions or extensions of the mud blanket, though generally prevalent, were not present everywhere, but that there were localised refugia where more normal, well-lit environments persisted. Such locations have not yet been found in Europe (Brauckmann, pers. comm.), though were certainly present in the Canning Basin, Australia [44, 63]. Another suggestion is that the schizochroal eye itself is highly specialised and might have been able to withstand even very dim light conditions. Whereas the trilobite still had some advantage from vision, it also finally died out because of the toxic water conditions.

Another group of 'heroes' are some proetids, which even, as the only remaining trilobite group, survived the 
Hangenberg Event and persisted until the late Permian [65-71]. They continued for another 90 million years after all other trilobites had become extinct. Recently described Permian proetids, exceptionally well preserved [72] how normal, large reniform eyes. Only two species of blind proetids have been described for the Permian [73, 74]. Various opinions have been expressed about how these last trilobites survived so long. The first is, as formulated for the late Devonian phacopids, that local, well-lit refugia persisted, and that it was from these that all of the latest trilobites arose [75]. Hahn et al. [71] proposed that probably most of the proetid trilobites became extinct at the Devonian/Carboniferous boundary, and that all the trilobites of the Permian descended from only four or five different species. The most important groups from which the Permo-Carboniferous trilobites derived seem to have arisen from the genus Waribole. During the following radiation, many ecological niches were colonised, though in shape these trilobites remained quite similar (Hahn et al. 1994). A similar point of view is shared by Feist and his co-workers, at least for the genera Pudoproetus and Brachymetopus. These genera seem just to have survived somewhere in the platform areas of the sea since they can be traced across the Devonian/Carboniferous boundary $[68,76]$.

At the end of the Permian, about 252 Mya, during 'the Great Dying', about $75 \%$ of all terrestrial, but even $~ 95 \%$ of all marine species died out [77, 78]. The reasons were complex, and no single event can be defined. One important cause probably was another kind of continuous megavolcanism in the Siberian traps lasting for a time interval of 165.000 bis 600.000 years, ensuing gigantic coal and gasfires and explosions [79]. Basalt flows of more than $3 \mathrm{~km}$ thickness arose, covering 7 millions of $\mathrm{km}^{2}$ [80]. The consequence was a warming of the seas of at least 5 degrees. The high volcanic emission of hydrogen chloride caused a drastic decline of the ph-values, which killed most of the marine organisms, and set free enormous masses of methane, and furthermore the temperatures quite rapidly increased by furthermore 5 degrees due to greenhouse effects [80]. Finally the fusion of the great continents to the megacontinent 'Pangaea' caused a drastic decline of shelf areas, coupled with a global lowering of sea level of up to 280 metres. Additionally, there is strong evidence for an impact event at the Permo-Triassic boundary, considered by some as the origin of the high volcanic activity mentioned before $[80,81]$. The trilobites, like so many other invertebrates, did not survive these multiple extinction events. At the end they became very small Figure $2 \mathrm{I}$, most of them were about $1 \mathrm{~cm}$ or smaller, in many of them their shell was less sculptured than were the shells of their predecessors [73, 74]. Many species became endobenthic, living within the sediment, and were blind, though in some species the eyes remained functional to the end Figure $2 \mathrm{H}, \mathrm{L}$.

While Feist and McNamara argue in their papers about Late Devonian trilobites from western Australia that eye reduction can be related to small body size, which arose from low nutrient status of the environment $[37,62]$ (Feist and McNamara 2013, 2016), it might be worthwhile briefly to consider the relevance of costs that the maintenance of an eye will afford. There have been attempts to describe the energy-consuming metabolic pathways in human eyes (e.g. [82] Wong-Riley 2010), to illuminate the high diversity and complexity of energy metabolisms in the different arthropod groups by far would exceed the capacity of this article. We should, however, consider, the costs not only of establishing an eye morphologically in the first place, but also of maintaining it thereafter, and costs that would be saved if there were no vision.

Chemical energy equivalents, such as ATP (Adenosine-tri-phosphate), GTP (Guanosine-triphosphate) and others store energy, transport it through the organism and set the energy free by dephosphorilation. So, for example ATP changes to ADP (Adenosine-di-phosphate) +1 phosphate, and $-32,3 \mathrm{~kJ} / \mathrm{mol}$ of energy (or $64,6 \mathrm{~kJ} / \mathrm{mol}$ if both phophategroups are left of), which allows endotherm chemical reactions throughout the whole metabolism. Text books e.g. [83, 84] tell us that in any process of phototransduction light induces a change of configuration in the photopigments, the rhodopsin for example. The photopigments in arthropods are housed in the membranes of microvilli of the sensory cells that (in an apposition compound eye) fuse to a central unit, the rhabdom. If the energy of light changes the configuration of the visual pigment, a cascade of processes at the sensory membrane starts, producing a slight electric signal (often at about $\sim 70 \mathrm{mV}$ ). This signal is transduced to neural centres of processing, where all further processing again is coupled to processes at nervous membranes. To bring the sensory membranes back to their initial conditions, that they may become functional again, and to maintain the processing instances of the nervous system working, needs a high amount of the energy-equivalents mentioned before. Thus the number of them needed for vision depends on the number of photons received, and the intensity/complexity of processing the signals. All these energy-equivalents, however, in times of scarcity could have been used elsewhere in the metabolic system.

Further energy saving aspects may be considered. It may be worthwhile to invest energy and to establish and maintain an eye, if there are predators that will extinguish yourself and your population, if you could not see them. No saved ATPs will help you then. There is no need, however, to invest into eyes, when you live in a(-n ideal) predatorless surrounding filled with nutriance that can be reached with any movement you do. This may be roughly conceivable for small Ediacaran organisms grazing on ocean-wide algae mats. 


\section{4- Miniaturisation, Specialisation and Eye Reduction}

\section{4-1- A Tiny Trilobite}

As mentioned before, eye loss often is linked to a decreased or absent level of light, for animals living in the depths, dark caves or within the sea-floor sediment. At first sight it seems to be problematic also for very small compound eyes, as in tiny arthropods, to capture enough photons to work effectively. However, there are many examples in tiny insects living today, for instance, where very small eyes are perfectly functional. They had to evolve, however, appropriate strategies to be so. Many of them have wide acceptance angles of light for each facet (often sacrificing resolution by that), a wide aperture (lens), a relatively wide receptive structure (wide rhabdom) compared to larger eyes, and/or they may have more sensitive receptors. Adaptations like these are necessary, in tiny trilobites as in very small living organisms. During about the last ten million years of the Cambrian, the Furongian, there lived many genera of the trilobite family Olenidae, adapted to low oxygen conditions. One species is a miniaturised form, less than 2 millimeters in size - Ctenopyge ceciliae Clarkson and Ahlberg 2002 Figure 1I-M. It is characterised by long thin spines, which in this very small animal would have acted to reduce sinking by frictional retardation. But the drag effects of these coupled with the miniscule size of the whole organism surely did not allow it to steer actively through the water column. It is the earliest recorded trilobite to invade the planktonic realm. It is most likely that this trilobite lived as a planktonic organism. C. ceciliae had well developed compound eyes, those of the earliest developmental stage having 6-9 facets, the adults with up to 50. In this miniscule trilobite the space for building a compound eye is greatly restricted, and in such an eye there is a very real conflict between having installed an adequate number of lenses to achieve a good acuity of the eye, and to build lenses with an aperture wide enough to capture enough photons to allow the compound eye to function. Furthermore, [26], p. 483) estimates that in order to absorb 95\% of the incident light, the receptive structure, the rhabdom, and thus an ommatidium should have a length of at least $600 \mu \mathrm{m}$ (also compare [27]), so a certain depth is also necessary. The Eye Parameter is a commonly used measure that describes the tradeoff between acuity and sensitivity in compound eyes [77, 78, 87-89]. For a high resolution, among other characteristics, a compound eye should have a small interommatidial angle $\Delta \phi$, and many facets. To establish as many facets as possible these should be small. Smaller lenses, however, have a lower aperture and hence capture fewer photons than do larger lenses, thus sensitivity of the eye may be lost. The authors given above could show that the expression $\mathrm{D} \cdot \Delta \phi=\mathrm{p}$, with $\mathrm{D}$ diameter of the lens, and $\mathrm{p}$ the Eye Parameter, is an appropriate expression to characterise the optimisation the organisms establish between the efforts of sensitivity and acuity, while working at threshold perception. (Actually $\Delta \phi$ should be substituted by the receptor acceptance angle $\Delta \rho ; \Delta \phi$, however, can be expressed by a $\Delta \rho$, while the factor a can be taken from [78, Figure 12]. Between $\mathrm{p}$ and luminance of light and the Eye Parameter there is a non-linear relation, but [85] was able to show that $\mathrm{p}$ for bright-light insects lies between 0.45 and 1 [ $\mu \mathrm{m} \mathrm{rad}$ ], for diurnal insects between 1 and 2 [ $\mu \mathrm{m} \mathrm{rad}$ ], the eye of a nocturnal dragonfly shows a petween 2 and $3[\mu \mathrm{m} \mathrm{rad}]$ and $p$ for the eyes of deep sea crustaceans lies between 3 and $6[\mu \mathrm{m} \mathrm{rad}]$ or is larger. For the tiny trilobite Ctenopyge ceciliae it may be calculated for the adult eye that $\mathrm{p}=7.9[\mu \mathrm{m}$ rad], indicating a dark light adapted eye, which is inappropriate for an organism living planktonic in the photic zone [90].

The interpretation is that due to the limited space for accommodating a proper compound eye with long rhabdoms, and especially with an optimised acuity due to a minimised $\Delta \phi$; the lenses (and rhabdoms) become widened to capture enough photons to make the rhabdoms work sufficiently, while the rhabdoms can be shortened in this small, flat trilobite - this, however, limits the possibility of a higher number of lenses. It is intriguing that the visual surface of the eye is set at on a kind of socle, establishing a relatively flat surface Figure 1M. This is useful for achieving acuity as high as possible, because the divergence angles of the optical axes of the facets $\Delta \phi$, corresponding to a fineness of scanning, becomes smaller on a flat surface than on a spherical Figure 1E, J, K. The instrumental Eye Parameter here loses its normal function of indicating a light condition to which the organism is adapted - under the optimal light conditions as in the photic zone it becomes instead a measure of miniaturisation and successful reduction of the system.

\section{4-2- Tiny 'Orsten' Fossils}

Approximately age-equivalent are the excellently, and three dimensionally preserved so-called 'Orsten' fossils from the Cambrian of Sweden. Their phosphatised preservation allows the retention of the finest details, such as setae of $1 \mu \mathrm{m}$ thickness - and the facets of their compound eyes [91, 92]. Some crustaceans of this fauna, such as Henningsmoenicaris scutula (Walossek \& Müller, 1990), possess compound eyes that are by far too small to form proper images. H. scutula, however, developed sophisticated strategies how estimate distance and how to trace and persue potential prey visually [93].

Among the 'Orsten'- fauna are other small crustaceans, Cambropachycope clarksoni Walossek and Müller 1990, and Goticaris longispinosa Walossek and Müller 1990, two sister species. Both have a length of not more 1mm, their entire head is not more than $200 \mu \mathrm{m}$ long. Their appendages indicate that both were predators, their eyes show that their predatory life style was visually guided. Probably because two separate compound eyes would have been too small to be built functionally, the eyes were fused to a single eye, placed in the front of the head as a prominent sensory organ 
dominating the entire head. Comparable solutions are found in predatory waterfleas living today, such as of the genus Polyphemus. Because in Ctenopyge ceciliae Clarkson and Ahlberg, 2002 the visual surface is relatively flat, thereby minimising the $\Delta \phi$, and the Eye Parameters of both crustaceans tell us that their larvae lived under dim light conditions, in greater depth or that they were crepuscular. The adults of $\mathrm{C}$. clarksoni lived in the photic zone and were active during the day, G. longispinosa either lived at a greater depth or were active later in the day. The appendages indicate that it was a 'sit-and-wait-predator', while C. clarksoni was an actively swimming hunter (Schoenemann et al. in prep.).

The most remarkable structural modification, however, is that $\mathrm{C}$. clarksoni shows a differentiated visual surface. The upper third of the visual surface has larger lenses than the rest $(\sim 36 \mu \mathrm{m}$ vs. $\sim 25 \mu \mathrm{m})$, and is tilted, about $\sim 50$ degrees against the surface of the water. This angle coincides with the angle of maximum amount of vertically polarised light during the evening dusk. As the smaller the angle of sunlight with respect to the water surface becomes, this increases. The orientation of the compound eye, or parts of it as here, can be observed in many waterfleas of today, and it is well known that waterfleas are sensitive and orientate towards polarised light, and vertically migrate during the day. These examples show that even reduced, miniaturised eyes can well be highly specialised and sophisticated.

There is another very small crustacean in the 'Orsten' fauna, so far undescribed. Here the entire compound eye is not larger than $\sim 40 \times \sim 20 \mu \mathrm{m}$, containing about 20 facets on a slightly domed surface. The facets are $\sim 7-8 \mu \mathrm{m}$ long, maximal $\sim 5 \mu \mathrm{m}$ wide and densely packed. For physical reasons this system is by far too small to accommodate the necessary elements of a complete apposition compound eye, with several receptor cells, a rhabdom etc. There is probably only enough space for a single sensory cell below a slightly focusing cupola. Whether this is an early developmental stage of a compound eye during ontogeny (the crustacean shown here surely is an instar), or of phylogeny - or both - must remain undecided [94].

\section{5- Parasites}

Parasites, today often blind, rarely appear in the fossil record, where they seem to be rather similar to their modern relatives, and to have hardly changed during the course of times. Endoparasites, once they had found an appropriate host, have no reason to hunt or even to move as do many of the haematophage arthropods, such as midges, horseflies and others, which are sometimes well equipped with enormous eyes. For invasive endoparasites, there is no need for further optical orientation, and so they often lost their eyes during evolution. Most endoparasites are small and soft bodied and so the fossil record of them is sparse [95]. Many of the parasitic taxa known from the fossil record seem to have remained relatively unchanged in their general morphology, and the patterns of host associations have been stable over many millions of years. Thus it is challenging, and rare to find evolutionary sequences [95]. This is surely true for the giant fleas from the Mesozoic era of China, much discussed at the present time, which fed on the blood of feathered 'reptilians' and radiated to mammalian and bird hosts later in the Cenozoic [95]. Although not so far described in greater detail, the fossils show small, reduced eyes, not dissimilar to those of the fleas of today.

Pentastomids (Maxillopoda, Crustacea,'tongue worms') today are blind obligate parasites living inside the respiratory organs of birds, reptiles and mammals. Whereas crustaceans typically possess very sophisticated compound eyes, blind crustaceans are not uncommon and can be found among deep sea, and cave dwelling crustaceans. Pentastomids of the 'Orsten'-fauna (here $\sim 497 \mathrm{Mya}$ ) had no conspicuous eyes, they (probably) were blind, but retain appendages and in general a body plan typical of crustaceans. They may have lived as larvae floating close to the Cambrian seafloor, but in the absence of higher vertebrates it is uncertain what they fed on [92, 96]. They might originally have been ectoparasites of marine arthropods or conodont animals during or prior to the Silurian [97] and an upward incorporation into jawed vertebrates when they had originated has been suggested ([95], p. 416). Thus, a reduction of eyes in the evolutionary line towards pentastomids may have taken place even early in the Cambrian.

Agnostoids, traditionally regarded as trilobites, but now, on account of limb morphology considered by many authorities to be closer to a crustacean line of descent [98], are invariably blind Figure 2G. Amongst this group there was probably a diversification of life styles. Some may have been ectoparasites (Barrande, 1852), but there is no clear evidence for or against this suggestion (Clarkson pers. comm.).

\section{6- Conclusion}

Thus, in conclusion different forms of eye reduction, and of development of blindness can be observed in the fossil record, as exemplified in trilobites as the most dominant arthropod group during the Paleozoic. In sequences through related groups of trilobites the reduction of eyes in different modes can be observed stepwise during the progression of great extinction events, notably the Kellwasser- and Hangenberg Event at the end of the Devonian times. The invasion of deep water areas during the Great Biodiversification Event during the Ordovician also led to economizing energy eye loss, as did the occupation of the ecological niche endoparasitism. Finally it seems possible that the reduction of eyes can be used to build higher sophisticated systems, as in the phacopid trilobites, which is an object of current research. 
Small forms as the tiny trilobite Ctenopyge ceciliae Clarkson and Ahlberg, 2002, of necessity show very small eyes, adapted well to this miniaturisation by the development of large lenses capturing sufficient light to work with efficiency, consequently a low number of lenses installed, and a flat visual surface to gain finest possible scanning of the environment. Other examples are the tiny crustaceans from the Cambrian 'Orsten'- fauna, combining two compound eyes to one, even possibly enabling the differentiation of specialised visual surfaces with different functions, or developing sophisticated strategies for small non-image forming compound eyes to pursue prey.

\section{7- Acknowledgements and Funding}

We wish to express our gratitude to the reviewers, the editors, to Carsten Brauckmann, TU Clausthal and Euan N.K. Clarkson, University of Edinburgh for their helpful discussions, and Anne Germund, Cologne for her help with some of the computer drawings, as Lauren Summer-Rooney and Megan Porter for organising the symposium 'Evolution in the Dark' so excellently. I am very grateful to the Company of Biologists, the Palaeontological Association (PA-GA201707), the American Microscopical Society, the Crustacean Society, and the Society of Integrative and Comparative Biology (divisions DEDB, DNB, DPCB, DEE and DIZ) for their funding and support.

\section{8- Conflicts of interest}

The authors declare no conflict of interest.

\section{9- References}

[1] Land, M. F., and Fernald, R. D. "The evolution of eyes". Annual Review of Neuroscience, 15, 1992, 1-29. doi: 10.1016/S09594388(00)00114-8.

[2] Jenkins, R.J. F. "Functional and ecological aspects of Ediacaran assemblages". In Origin and Early Evolution of the Metazoa; Lipps,H. J. and P.W. Signor, P. W., Eds.; Plenum Press, New York and London, 1992; pp. 131-176. doi: 10.1007/978-1-48992427-8

[3] Vickers-Rich, P., and Komarower, P. "The rise and fall of the Ediacaran biota". Geological Society of London, London, 2007, 275 pp. doi: 10.1144/SP286.0.

[4] Brasier, M. "Darwin's lost world: the hidden history of animal life". Oxford University Press, Oxford, 2009,304 pp. doi: 10.1016/S0262-4079(09)60382-1.

[5] Land, M. F., and Nilsson, D. E.” Animal eyes”. Oxford University Press, Oxford, 2012, 271 pp. doi: 10.1111/j.14636395.2012.00570.x.

[6] Schoenemann, B., Liu, J-N., Shu, D-G., Han, J-A. \& Zhang, Z-F. “A Miniscule Optimised Visual System in the Lower Cambrian”. Lethaia, 2009; 42, 265-273. doi: 10.1111/j.1502-3931.2008.00138.x.

[7] Schoenemann, B., and Clarkson E. N. K. "At First Sight - Functional Analysis of Lower Cambrian eye systems". Palaeontographica A, 2012; 297,123-149. doi: 10.1127/pala/297/2012/123.

[8] Schoenemann, B., and Clarkson E. N. K. "The eyes of Leanchoilia". Lethaia, 2012; 45, 524-531. doi: 10.1111/j.15023931.2012.00313.x.

[9] Lee, M. S.; Jago, J. B.; García-Bellido, D. C.; Edgecombe, G.D.; Gehling, J.G., and Paterson, J. R. "Modern optics in exceptionally preserved eyes of early Cambrian arthropods from Australia". Nature, 2011; 474, 631-634. doi: 10.1038/nature10097.

[10] Paterson, J.R., García-Bellido, D.C., Lee, M.S., Brock, G.A., Jago, J.B. And Edgecombe, G.D. 2011. “Acute vision in the giant Cambrian predator Anomalocaris and the origin of compound eyes". Nature, 480; 237-240. doi: 10.1038/nature10698.

[11] Zhao, F.-C., Bottjer, D. J., and Hu, S.-X. “Complexity and diversity of eyes in Early Cambrian ecosystems.” Sci. Rep. 2013; 3, 2751. doi: 10.1038/srep02751.

[12] Strausfeld, N. J.; Ma, X.-O., Edgecombe, G. D.; Fortey, R. A.; Land, M. F.; Liu, Y., Cong, P.-Y., and Hou, X.-G. “Arthropod eyes: The early Cambrian fossil record and divergent evolution of visual systems”. Anthrop. Struct. Dev., 2016; 45, $152-172$. doi: 10.1016/j.asd.2015.07.005.

[13] Reis, M.; Tharwornwattana, Y.; Angelis, K.; Telford, M. J.; Donoghue, C. J. , and Yang, Z. "Uncertainty in the timing of origin of animals and the limits of precision in molecular timescales". Curr. Biol.; 25, 2939-2950. doi: 10.1016/j.cub.2015.09.066.

[14] Parker, A. R. "Colour in Burgess Shale animals and the effect of light on evolution in the Cambrian". Proc. Roy. Soc. London B, 1998; 265,967-972. doi: 10.1098/rspb.1998.0385.

[15] Pentecost, Michael J. "In the Blink of an Eye." Journal of the American College of Radiology 7, no. 6 (June 2010$): 396$. doi: 10.1016/j.jacr.2010.03.003. 
[16] Schoenemann, B., Pärnaste, H., and Clarkson, E. N. K. "Structure and function of a compound eye, more than half a billion years old". Proceedings of the National Academy of Sciences of the United States of America (PNAS), 2017; 114, 13489-13494. doi: 10.1073/pnas.1716824114.

[17] Wilkinson, M.; Garbout, A., and Samantha, M. M. “The visual system of caecilian amphibians”. Integr. Comp. Biol., 2018; accepted.

[18] Emerling, C. A. "Regressed but Not Gone: Patterns of Vision Gene Loss and Retention in Subterranean Mammals". Integr. Comp. Biol., 2018; icy004. doi: 10.1093/icb/icy004.

[19] Summer-Rooney, L. H.; Sigwart, J. D.; Smith L; Mcafee, J., and Wlliams, S. T. "Repeated eye reduction events reveal multiple pathways to loss in deep sea snails". Integr. Comp. Biol., 2018; accepted.

[20] Tierney, S. M.; Langille, B.; Humphreys, W. F.; Austin, A. D., and Cooper, S. J. B. Massive parallel regression: genetic mechanisms for eye loss amongst subterranean diving beetles. Integr. Comp. Biol., 2018, icy035. doi: 10.1093/icb/icy035.

[21] Stern, D. B., and Crandall, K. A. "Convergent and divergent transciotome evolution in the eyes of blind cave crayfish". Integr. Comp. Biol., 2018, icy029. doi: 10.1093/icb/icy029.

[22] Yoshizawa, M.; Hixon, W., and Jefferey W.R. "Neural Crest Transplantation Reveals Key Roles in the Evolution of Cavefish Development”. Integr. Comp. Biol., 2018, 58; 411-420. doi: 10.1093/icb/icy006.

[23] Re, C.; Fišer, Ž.; Perez, J.; Tacdol, A.; Trontelj, P., and Protas, M. E. "Common genetic basis of eye and pigment loss in two distinct cave populations of the isopod crustacean Asellus aquaticus”. Integr. Comp. Biol., 2018; 58, 421-430. doi: 10.1093/icb/icy028.

[24] Valdez-Lopez, J.; Mary W Donohue, M. W.; Bok M. J., Wolf, J., Cronin T. W., and Porter M. L. "Sequence, Structure and Expression of Opsins in the Monochromatic Stomatopod Squilla mantis". Integr. Comp. Biol., 2018; $386-397$. doi: 10.1093/icb/icy007.

[25] Exner, S. „Die Physiologie der facettierten Augen von Krebsen und Insekten“. 1891, Deuticke, Leipzig, Wien, 206 pp.

[26] Land, M. F. "Vision in Invertebrates". In Handbook of Sensory Physiology VII/6B (Autrum, H. Ed.), 1981; Springer, Berlin, pp. 471-592. doi: 10.1002/iroh.19760610313.

[27] Cronin, T.W.; Johnson, N. S.; Marshall, N.J., and Warrant, E. J. "Visual Ecology". 2014; Princeton University Press, Princton, Oxford, 432 pp. doi:10.4172/2161-0940.1000180.

[28] Fortey, R. A. “Classification”. In Treatise on Invertebrate Paleontology, Part O, Arthropoda I. Trilobita. Revised, (ed. Kaesler, R. L.), 1998, Geological Society of America and University of Kansas Press, Lawrence, pp. $289-302$. doi: 10.1111/j.1558-5646.1965.tb01697.x

[29] Fortey R. A., and Whittington, H. B. "The Trilobita as a natural group". Hist. Biol. 1989; 2, 125-138. doi: 10.1080/08912968909386496.

[30] Scholtz, G., and Edgecombe, G. D. "Heads, Hox and the phylogenetic position of trilobites". Crustacean Issues, 2005; 16, 139166, doi: 10.1201/9781420037548.ch6.

[31] Legg, D. A.; Sutton, M. D., and Edgecombe, G. D. "Arthropod fossil data increase congruence of morphological and molecular phylogenies”. Nature Communictons, 2013. doi: 10.1038/ncomms3485.

[32] Fortey R. A., and Owens, R. M. “Feeding habits in trilobites”. Palaeontology, 1999; 42,429-465. doi: 10.1111/1475-4983.00080.

[33] Clarkson E. N. K.; Levi-Setti, R., and Horváth, G. "The eyes of trilobites: The oldest preserved visual system”. Arthrop. Struct. \& Dev. 2006; 35, 247-259. doi: 10.1016/j.asd.2006.08.002.

[34] McGhee, G. R. “The Late Devonian Mass Extinction: the Frasnian/Famennian Crisis”. Columbia University Press, New York, 1996; 303 pp. doi: 10.1017/S0016756800024705.

[35] Algeo T. J. ; Scheckler, S. E., and Maynard, J.B. „Effects of the Middle to Late Devonian spread of vascular land plants on weathering regimes, marine biota, and global climate". In Plants Invade the Land: Evolutionary and Environmental Approaches, P. E. Gensel P. E., and Edwards, D. P., EDS., Columbia Univiversity Press, New York, 2001; pp. 213-236. doi: 10.7312 /gens11160.

[36] Sole, R. V., and Newman, M. "Extinctions and Biodiversity in the Fossil Record" - Volume Two, The earth system: biological and ecological dimensions of global environment change. In Encyclopedia of Global Environmental Change, T. Munn Ed., John Wiley \& Sons, Hoboken (Belgium). 2001, pp. 297-391. doi: 10.1007/s00114-003-0421-8.

[37] McNamara K. J., and Feist R. "The effect of environmental changes on the evolution of Late Devonain trilobites from the northern Canning Basin, Western Australia”. Geol. Soc. London, Spec pub., 2016; 423, 251-271. doi: 10.1144/SP423.5. 
[38] Caplan M. L., and Bustin R. M. "Devonian-Carboniferous Hangenberg mass extinction event, widespreadorganic-rich mudrock and anoxia: causes and consequences". Palaeogeography, Palaeoclimatology and Palaeoecology 1999; 148, $187-207$. doi: 10.1016/S0031-0182(98)00218-1.

[39] Sallan, L. C., and Coates, M. I. "End-Devonian extinction and a bottleneck in the early evolution of modern jawed vertebrates". Proceedings of the National Academy of Sciences of the United States of America (PNAS) 2010; 107, 10131-10135. doi: 10.1073/pnas.0914000107.

[40] Marynowski, L.; Zatoń, M.; Rakociński, M.; Filipiak, P.; Kurkiewicz, S., and Pearce, Tj. "Deciphering the upper Famennian Hangenberg Black Shale depositional environments based on multi-proxy record". Palaeogeography, Palaeoclimatology, Palaeoecology 2012; 346/347, 66-86. doi: 10.1016/j.palaeo.2012.05.020.

[41] Racki, G. "Toward understanding Late Devonian global events: few answers, many questions". In Understanding Late Devonian and Permian-Triassic Biotic and Climatic Events: Towards an Integrated Approach, Over, D. J., Morrow R., and P. B. Wignall, P. B. Eds., Elsevier, Amsterdam. 2005; pp. 5-36.

[42] Algeo T. J., and Scheckler, S. E. "Terrestrial-marine teleconnections in the Devonian: links between the evolution of land plants, weathering processes, and marine anoxic events". Phil. Trans. Roy. Soc. London B 1998; 353, 113-130. doi: 10.1098/rstb.1998.0195.

[43] Algeo T. J.; Berner, R. A.; Maynard J. P., and Scheckler, S. E. "Late Devonian oceanic anoxic events and biotic crises: "Rooted" in the evolution of vascular land plants?" GSA Today 1995; 5, 63-66. doi: 10.5194/cp-2017-112.

[44] McNamara K. J., and Feist, R. "Patterns of trilobite evolution and extinction during the Frasnian/Famennian mass extinction Canning Basin., Western Australia. In Advances in trilobite research Rabano I.; Gozalo, R., and García -Bellido, D), Guardernos del Museo Geominero 2008; 9, 269-274. doi: 10.13140/2.1.1806.9283.

[45] Schoenemann, B. , and Clarkson E. N. K. "Discovery of some 400 million year-old sensory structures in the compound eyes of trilobites”. Sci. Rep. 2013; 3, 1429. doi: 10.1038/srep01429.

[46] Clarkson, E. N. K., and Zhang, X-G. Ontogeny of the Carboniferous trilobite Paladin eichwaldi shunnerensis (King, 1914). Transa. Roy. Soc. Edinb.: Earth Sci.1991; 82, 277-295. doi: 10.1017/S026359330000417X.

[47] Strauss cited after: Hesse, R. \& Dorflein, F. „Das Sehen der niederen Tiere“ (Vision in lower organisms). Gustav Fischer Verlag, Jena, 1909; 568 pp.

[48] Nilsson, D.E. \& Osorio, D. "Homology and parallelism in arthropod sensory processing". Arthropod relationships 1997; 55, 333-347. doi: 10.1007/978-94-011-4904-4_25.

[49] Richter, R. \& Richter, E. „Die Trilobiten des Oberdevon“. Beiträge zur Kenntnis devonischer Trilobiten. IV. Abh.d.Preuß.Geol.LA 1926; 99, 1-314. doi: 10.5962/bhl.title.49511.

[50] Clarkson, E. N. K. "Environmental significance of eye-reduction in trilobites and recent arthropods". Marine Geology 1967; 5, 367-375. doi: 10.1016/0025-3227(67)90046-1.

[51] Feist, R. “The late Devonian trilobite crises”. Historical Biology 1991; 5, 197-214. doi: 10.1080/10292389109380401.

[52] Feist, R. "Effect of paedomorphosis in eye reduction on patterns of evolution and extinction in trilobites". In Evolutionary Change and Heterochrony; Holland P. W. A. Ed.; Wiley, Chichester; 1995. pp. 225-244. doi: 10.1046/j.1420-9101.1996.9061034.x.

[53] Feist, R., and Clarkson, E. N. K. "Environmentally controlled phyletic evolution, blindness and extinction in Late Devonian tropidocoryphine trilobites”. Lethaia 1989; 22, 359-373. doi: 10.1111/j.1502-3931.1989.tb01435.x.

[54] Feist, R., and Schindler, E. “ Trilobites during the Frasnian Kellwasser crisis in Eurpean Late Devonian cephalopod limestones”. Courier Forschungsinstitut Senckenberg 1994; 169, 195-223.

[55] Feist, R., Mcnamara, K. J., Crônier, C., and Lerosey-Aubril, R. "Patterns of extinction and recovery of phacopid trilobites during the Frasnian-Famennian (Late Devonian)”. Geol. Mag. 2009; 146,12-33. doi: 10.1017/S0016756808005335.

[56] Crônier, C., and Feist, R. "Evolution et systematique du groupe Cryphops (Phacopina, Trilobita) du Devonien superiere". Senckenbergiana Lethaea 2000; 79, 501-515. doi: 10.1007/BF03043651.

[57] Crônier, C. , Bartzsch, K., Weyer, D. , and Feist, R. "Larval morphology and ontogeny of a late Devonian phacopid with reduced sight from Thuringia, Germany”. J. Paleont. 1999; 73, 240-255. doi: 10.1017/S0022336000027748.

[58] Lerosey-Aubril, R. "Ontogeny of Drevermannia and the origin of blindness in late Devonian proetoid trilobites". Geol. Mag. 2006; 143, 89-104. doi: 10.1017/S0016756805001421.

[59] Lerosey-Aubril, R., and Feist, R. "Quantitative approach of diversity and decline in late Palaeozoic trilobites. In Global Biodiversity, Extinction Intervals and Biogeographic Perturbations through Time”; Talent, J. A. Ed.; Springer, Berlin, 2012; p. 
535-555. doi: 10.1007/978-90-481-3428-1.

[60] McNamara K. J., Feist, R., and Ebach, R. " Patterns of evolution and extinction in the last harpetid trilobites during the Late Devonian (Frasnian)”. Palaeontology 2009; 52, 11-33. doi: 10.1111/j.1475-4983.2008.00832.x.

[61] McNamara, K. J. "Evolutionary Change and Heterochrony". Wiley, Chichester 1995; 286 pp. doi: 10.1111/j.10958312.2001.tb01355.x.

[62] Feist, R., and McNamara, K. J. "Patterns of evolution and extinction in proetid trilobites during the Late Devonian mass extinction event, Canning Basin, Western Australia". Palaeontology 2013; 56, 229-259. doi:10.1111/j.1475-4983.2012.01191.x.

[63] Chatterton, B. D. E. "Ontogenetic studies of Middle Ordovician trilobites from the Esbataottine Formation; Mackenzie Mountains, Canada”. Palaeontographica A 1980; 171, 1-74.

[64] Struve, W. "Beitrage zur Kenntnis der Phacopina (Trilobita), 9:Phacops (Omegops) n. sg. (Trilobita; Ober-Devon)“. Senckenbergiana Lethaea 1976; 56, 429-451.

[65] Brauckmann, C. "Eine weitere Art der Cyrtosymbolinae mit vollständig erhaltenem Thorax (Trilobita, Ober-Devon)“. (Another species of Cyrtosymbolinae with a complete thorax.) Jahresberichte des naturwissenschaftlichen Vereins Wuppertal 1985; 38, 150-153.

[66] Brauckmann, C., and Hahn, G. "Trilobites as Index Fossils at the Devonian-Carboniferous Boundary". In The DevonianCarboniferous boundary, Paproth E., and Streel M. Eds., Courier Forschungsinstitut Senckenberg 1984; 67, pp. 11-14.

[67] Brauckmann, C. \& Koch, L. "Trilobiten aus dem Sauerland“. (Trilobites from the Sauerland). Westfalen im Bild, Paläontologie in Westfalen 1987; 4, 1-43.

[68] Brauckmann C., Chlupáč I. , and Feist, R. "Trilobites at the Devonian-Carboniferous Boundary”. In Devonian-Carboniferous Boundary. Streel, M., Sevastopulo, G., and Paproth, E., Eds; Ann. Soc. géol. Belg. 1993; 115, 507- 518.

[69] Hahn, G., and Hahn, R. "Die Trilobiten des Ober-Devon, Karbon und Perm. (The trilobites of the Upper Devonian, Carboniferous and Permian.)" In Leitfossilien (Index fossils); K.Krömmelbein, K. Ed.; Borntraeger, Stuttgart, $1975 ; 127$ pp. doi: 10.1017/S0016756800045295.

[70] Hahn, G., and Wunn-Petry, I. "Seltene Trilobiten aus der nasutus-Zone (Kulm-Fazies, Unter-Karbon) (Rare trilobites from the nastus-zone (Kulm, Lower Carboniferous).) “ Senckenbergiana lethaea 1983; 64, 237-255.

[71] Hahn, G., Hahn, R., and Brauckmann, C. “Trilobiten mit „Drevermannia-Habitus“ im Unter-Karbon (Trilobites with „Drevermannia-Habit“). Cour. Forsch. Inst. Senkenberg 1984; 169, 155-193.

[73] Owens, R.M. “A review of Permian trilobite genera”. Special papers in Palaeontology 1983; 30, 15-41.

[74] Owens, R. M. “The stratigraphical distribution and extinctions of Permian trilobites”. Special papers in Palaeontology 2003; 70, 377-397.

[75] Owens, R. M. "Pseudoextinctions in late Devonian proetide trilobites". Historical Biology 1994; 9, 7-22. doi: 10.1080/10292389409380498.

[76] Feist, R. \& Petersen, M. S. "Origin and spread of Pudoproetus, a survivor of the late Devonian trilobite crisis". J. Paleontol. 1995; 69, 99-109. doi: 10.1017/S0022336000026950.

[77] Benton, M. J. "When Life Nearly Died: The Greatest Mass Extinction of All Time”. Thames and Hudson, London, New York, 2003; 36 pp. doi: 10.1017/S0016756803218343.

[78] Bergstrom, C. T., and Dugatkin, L. A. "Evolution”. Norton, New York, 2012; 677 pp.

[79] Ogdena,D. E., and Sleep, N.H. "Explosive eruption of coal and basalt and the end-Permian mass extinction". Proceedings of the National Academy of Sciences of the United States of America (PNAS) 2011; 109, 59-62. doi: 10.1073/pnas.1118675109.

[80] Sobolev, S. V., Sobolev, A.V., Kuzmin, D.V., Krivolutskaya, N.A., Petrunin, A.G., Arndt, N.T., Radko, V. A., and Vasiliev, Y. R. "Linking mantle plumes, large igneous provinces and environmental catastrophes". Nature 2011; 477, 312-316. doi: 10.1038/nature10385.

[81] Retallack, G. J., Seyedolali, A., Krull, E.S., Holser, W. T., Ambers C. P.,and Kyte F. T. "Search for evidence of impact at the Permian-Triassic boundary in Antarctica and Australia". Geology 1998; 26, 979-982. doi: 10.1130/0091-7613(1998)026<0979:SFEOIA>2.3.CO;2.

[82] Wong-Riley, Margaret. "Energy Metabolism of the Visual System.” Eye and Brain (July 2010): 99. doi:10.2147/eb.s9078.

[83] Wehner, R., and Gehring W. “Zoologie“. Thieme, Stuttgart, 2007; 953pp. doi: 10.1002/biuz.200890037.

[84] Penzlin, H. "Lehrbuch der Tierphysiologie“ (Textbook of Animal Physiology). Spektrum Akademischer Verlag, Heidelberg, 
2009; 970 pp.

[85] Horridge, G. A. "Insects which turn and look”. Endeavour 1977; 1, 7-17. doi: 10.1016/0160-9327(77)90004-7.

[86] Horridge, G. A. "The separation of visual axes in apposition compound eyes”. Phil. Trans. Roy. Soc. London B 1978; 285, 159. doi: 10.1098/rstb.1978.0093.

[87] Snyder, A. W. “Acuity in Compound eyes: Physical Limitations and Design”. J. comp. Physiol. 1977; 116, $161-182$. doi: 10.1007/BF00605401.

[88] Snyder, A. W. "Physics of vision in compound eyes". In Comparative physiology and evolution of vision in invertebrates, Autrum, H. Ed.; Springer, Berlin 1979; pp. 225-313. doi: 10.1007/978-3-642-66999-6_5.

[89] Snyder, A. W., Stavenga, D. G., and Laughlin, S. B. "Spatial information capacity of compound eyes". J. comp. Physiol. 1977; 116, 183-207. doi: 10.1007/BF00605402.

[90] Schoenemann, B., Clarkson, E. N. K., Ahlberg, A., and Dies Álvarez, M. E. “A Tiny Eye Indicating a Planktonic Trilobite”. Palaeontology 2010; 53, 695-701. doi: 10.1111/j.1475-4983.2010.00966.x.

[91] Walossek, D. "The Upper Cambrian Rehbachiella and the phylogeny of Branchiopoda and Crustacea“. Fossils \& Strata 1993; 32, 1-202. doi: 10.1111/j.1502-3931.1993.tb01537.x.

[92] Castellani C., Haug, J. T., Haug, C., Maas, A., Schoenemann, B., and Waloszek, D. "Exceptionally well-preserved isolated eyes from Cambrian 'Orsten' fossil assemblages of Sweden”. Palaeontology 2012; 55, 553-566. doi: 10.1111/j.14754983.2012.01153.x.

[93] Schoenemann, B., Castellani, C., Clarkson, E. N. K, Haug, J. T., Maas, A., Haug, C., and Waloszek, D. "The sophisticated visual system of a tiny Cambrian crustacean: analysis of a stalked fossil compound eye”. Proc. Roy. Soc. London B 2012; 279, 13351340. doi: 10.1098/rspb.2011.1888.

[94] Schoenemann, B. “The eyes of a tiny 'Orsten' crustacean - A compound eye at receptor level?” Vis. Res. 2013; 76, 89-93. doi: 10.1016/j.visres.2012.10.013.

[95] Leung, T. L. F. "Fossils of parasites: what can the fossil record tell us about the evolution of parasitism?” Biol. Rev. 2017; 92 , 410-430. doi: 10.1111/brv.12238.

[96] Walossek, D., and Müller, K. J. "Pentastomid parasites from the Lower Palaeozoic of Sweden”. Trans. Roy. Soc. Edinburgh: Earth Sci. 1994; 85, 1-37. doi: 10.1017/S0263593300006295.

[97] Siveter, D. J., Briggs, D. E. G., Siveter, D. J., and Sutton, M. D. “A 425-Million-Year-Old Silurian Pentastomid Parasitic on Ostracods”. Curr. Biol. 2015; 25, 1632-1637. doi: 10.1016/j.cub.2015.04.035.

[98] Bergström, J., and Hou, X-G. "Early Palaeozoic non-lamellipedian arthropods. In Crustacea and Arthropod Relationships", Koenemann, S., and Ronald, A. J., Eds., Taylor and Francis, New York, 2005; pp. 75-93. 